УДК 347.124:332.025.28

DOI https://doi.org/10.32837/pyuv.v0i1(30).514

\author{
Н.Б. Москалюк \\ orcid.org/0000-0003-2972-3352 \\ кандидат юридичних наук, доцент, \\ завідувач кафедри безпеки, правоохоронної діяльності \\ та фінансових розслідувань \\ Тернопільського національного економічного університету
}

\title{
МЕХАНІЗМ КОРПОРАТИЗАЦІЇ ЯК ПЕРЕДУМОВА ДО ПРИПИНЕННЯ ПРАВА ДЕРЖАВНОЇ ВЛАСНОСТІ: ІСТОРИЧНІ АСПЕКТИ, СУЧАСНИЙ СТАН І ПЕРСПЕКТИВИ РОЗВИТКУ
}

Нині державна власність є актуальним об'єктом для наукового дослідження. Велика кількість об'єктів державної власності потребує підвищення ефективності управління ними, адже низька якість управління часто робить їх збитковими, вони набувають статусу тягаря для державного бюджету. Необхідно забезпечити прозорість процесів корпоратизації та приватизації, аби не втратити тих активів, які є стратегічними для держави та її економічної безпеки.

Одним із фундаментальних напрямів економічної політики України є трансформування відносин власності, роздержавлення, державна підтримка і захист всіх форм власності та господарювання. Одним із важливих засобів реалізації цього напряму є корпоратизація. Варто зазначити, що нині на порядку денному стоїть питання корпоратизації стратегічно важливих підприємств і їх перетворення. У зв'язку з цим не лише питання доцільності їх корпоратизації, а й визначення основних способів такого процесу мають розглядатися на основі кращого вітчизняного та іноземного досвіду.

Проблемам державної власності присвячували свої наукові здобутки багато вчених. Серед них О.М. Вінник, Л.В. Винар, О.В. Дзера, В.М. Коссак, Н.С. Кузнєцова, І.А. Селіванова, Я.М. Шевченко, В.С. Щербина та інші. Безпосередньо питання корпоратизації стали об'єктом наукових досліджень Д.І. Погрібного, І.В. Спасібо-Фатєєвої, Т.В. Кашаніної, О.Р. Кібенко, Д.В. Задихайла, Н.С. Глусь, А.Г. Бобкової, І.Т. Тарасова, В.І. Андрейцевої, С.В. Артаменка, В.М. Кравчук, Н.Н. Пахомова, С.М. Хеда та інших.

Попри значну кількість публікацій, які стосуються корпоратизації, більшість із них розглядають цей процес під кутом зору реалізації корпоративних прав держави. Напрям розгляду корпоратизації як передумови до втрати права державної власності вченими досліджений не достатньо. Також мало дослідженим залишається процес корпоратизації та його відмінність від інших форм припинення права державної власності. Все вказане вище і зумовлює актуальність обраної тематики дослідження.
Метою статті $є$ аналіз норм законодавства України, що регулює питання припинення права державної власності завдяки застосуванню механізму корпоратизації, виявлення прогалин і недоліків правового регулювання такого процесу, формування пропозицій і висновків у цій сфері.

Забезпечення ефективного використання державного майна та збільшення надходження до державного бюджету від державних підприємств нині є стратегічним завданням, яке ставиться перед Кабінетом Міністрів України. Реалізацію цього завдання Уряд вбачає у формуванні корпоративного сектора, важливим гравцем якого буде держава. Автор статті вважає, що корпоратизація відіграє зараз подвійну роль: вона здатна впливати на ефективність управління державною власністю і може стати тим лакмусовим папірцем, який вплине на рішення щодо доцільності чи недоцільності подальшого перебування конкретного об'єкта в державній власності.

Автор розглядає більш детально поняття та суть процесів корпоратизації, національної та іноземної практики ії впровадження, проблеми та перспективи такого механізму і його вплив на право державної власності.

В Указі Президента України «Про корпоратизацію підприємств" подано таке визначення корпоратизації: «Це перетворення державних підприємств, закритих акціонерних товариств, більш ніж $75 \%$ статутного фонду яких перебуває в державній власності, а також виробничих і науково-виробничих об'єднань, правовий статус яких раніше не був приведений у відповідність iз чинним законодавством, у відкриті акціонерні товариства» [1]. 3 цього визначення можна дійти висновку, що корпоратизація сприяє зміні організаційно-правової форми суб'єкта господарювання, але форма власності все ж залишається незмінною. В Указі також зазначається, що корпоратизація не є підставою чи способом приватизації.

Доктринальні тлумачення цього поняття здебільшого зводяться до того, що «суть корпоратизації полягає в реорганізації державного підприємства чи його об'єднання шляхом перетворення" [2, с. 234]. Отже, основною метою корпоратизації 
$€$ реорганізація державного підприємства, спрямована на вдосконалення управління об'єктами державної власності.

В історичному контексті корпоратизація в Україні була започаткована вже згаданим Указом Президента України «Про корпоратизацію підприємств» від 15 червня 1993 року № 210/93, який є чинним і нині. Цей Указ досить розширено визначає основну мету корпоратизації:

1) реформування управління державним сектором економіки;

2) підвищення відповідальності державних підприємств за результати економічної діяльності;

3) підготовка їх до приватизації [1].

3 вказаної послідовності вбачаться, що якщо реформування управління таки не досягне своєї мети і не відбудеться підвищення відповідальності державних підприємств за результати економічної діяльності, то це стане передумовою до підготовки їх до приватизації.

Починаючи трансформацію відносин власності в 1992 році, держава мала на меті проведення широкомасштабної зміни статусу державних підприємств. Проте тільки це не могло бути достатнім інструментом підвищення ефективності виробництва. Зокрема, це можна пояснити тим, що правові відносини власності - не реальні (економічні), а вольові (ідеальні) відносини, які не утворюють субстанції виробничих відносин і через це перебувають поза сферою виробництва [2, с. 235]. Важливою властивістю реалізації акціонерної власності є управління цим процесом, без чого така власність не реалізується взагалі.

3 початку свого заснування корпоратизація відбувалася паралельно із приватизаційними процесами в Україні. Якщо проаналізувати історичний шлях розвитку ринкових механізмів, то їх взаємозв'язок чітко простежується. Технологія першого етапу приватизації була закладена у приватизаційне законодавство 1992 року. На той момент переважали соціалістичні стереотипи, консервативність населення, економічне панування директорів державних підприємств і голів колгоспів та радгоспів, елементарне незнання ринкових механізмів. Тому на першому етапі приватизації (1992-1998 рр.) 96\% об’єктів виявилися в руках не просто вітчизняного інвестора, а здебільшого інвестора без грошей і без ринкового досвіду; $63 \%$ малих і середніх підприємств було приватизовано трудовими колективами [2, с. 236]. Результатом масової приватизації стало недоотримання інвестицій, розподіл власності серед дрібних акціонерів, управління підприємствами здійснювалося тими ж кадрами, що не підвищило ефективність їхньої діяльності.

Корпоратизація ж розгорнулася на початку першого етапу приватизації і була задумана як етап підготовки до приватизації. Але розпорошення ак- ціонерної власності на першому етапі призвело до іншоїкрайності: напідприємстві створювався один акціонер - держава без подальшої приватизації.

Варто зазначити, що другий етап приватизації був пов'язаний із прийняттям Указу Президента України «Про невідкладні заходи щодо прискорення приватизації в Україні» від 29 грудня 1999 р. та зі зміною методів проведення приватизації, які полягали у відмові від розпорошення власності в процесі приватизації великих і середніх підприємств, а також із продажем контролю над ними в одні руки, з початком «грошової приватизації» за принципами, які будувалися на світовому досвіді.

В цей час Верховна Рада України змінила стратегію процесу корпоратизації, узаконивши існування підприємств, які не підлягали приватизації, але могли бути корпоратизованими. Так, 7 липня 1999 р. було прийнято Закон України «Про перелік об’єктів права державної власності, що не підлягають приватизації» № 847-XIV. Цей закон мав два додатки із переліками підприємств. До нього часто вносилися зміни. 2019 року закон втратив чинність. Цей факт, на думку автора статті, також вніс неабиякі зміни в подальше історичне майбутнє процесу корпоратизації.

Варто зазначити, що Кабінетом Міністрів України був розроблений і внесений на розгляд Проект Закону України «Про корпоратизацію державних підприємств» від 1 серпня 2012 року за № 11057, який мав регулювати правові, економічні й організаційні відносини, пов'язані з перетворенням державних комерційних підприємств у державні акціонерні товариства, та був спрямований на забезпечення економічної безпеки і захисту інтересів держави [3]. Вважалося, що порядок проведення процесу корпоратизації повинен визначатися базовим Законом України «Про корпоратизацію державних підприємств», а не підзаконним нормативно-правовим актом. Проте закон так і не був прийнятий.

На початку 2019 року експерти доопрацювали Проект Закону України «Про особливості перетворення державних унітарних комерційних підприємств оборонно-промислового комплексу в акціонерні товариства та їх приватизацію», який мав врегульовувати питання корпоратизації, приватизації і розпорядження майном підприємств оборонно-промислового комплексу, але вказаний законопроект не набув статусу закону. Важливо зазначити, що акціонерні товариства в Україні можуть бути створені шляхом реорганізації чи виділення, корпоратизації, приватизації, корпоратизації і подальшої приватизації. Більшість із них створена трьома останніми способами та пов'язана з участю держави як акціонера.

Щодо взаємозв'язку процесів корпоратизації та приватизації думки вчених розходяться. Одні 
з них, до яких належить Ю. Дзера, вважають, що «корпоратизація державних унітарних підприємств через їх перетворення у господарські товариства є лише передумовою для подальшої приватизації майна, переданого державою до їх статутного фонду (капіталу)»[4]. В той же час інші, серед яких і В.В. Васильєва, вважають, що корпоратизація не є підставою або способом приватизації. Найочевиднішою з відмінностей цих двох процесів є процедура їх здійснення [5]. Автор статті не є прихильником першої концепції, вважаючи, що і корпоратизація за умови не вирішення питання з ефективністю управління є передумовою до приватизації, зміни форми власності. Звісно, не всі випадки корпоратизації призводять до приватизації, але передумовою таких процесів вони роздержавлення вони можуть бути.

Процедура корпоратизації складається з таких етапів:

1) затвердження рішення про корпоратизацію державного підприємства;

2) створення комісії з корпоратизації;

3) підготовка акта оцінки вартості цілісного майнового комплексу відповідно до методики оцінки вартості об’єктів приватизації підприємства, проєкту плану розміщення акцій і проєкту статуту акціонерного товариства;

4) затвердження засновником акта оцінки вартості цілісного майнового комплексу, прийняття рішення про створення акціонерного товариства та затвердження його статуту;

5) державна реєстрація акціонерного товариства та його статуту. Припинення повноважень комісії з корпоратизації;

6) затвердження персонального складу наглядової ради, правління, ревізійної комісії акціонерного товариства Міністерством економіки, Мiністерством фінансів і Фондом державного майна України;

7) реєстрація випуску акцій;

8) укладення договору з реєстратором або зберігачем і депозитарієм чи отримання ліцензії на самостійне ведення реєстру власників іменних цінних паперів [6, с. 49].

Здебільшого підготовка до корпоратизації могла тривати від 2 до 5, а деколи і більше років та складалася із проведення реструктуризації, залучення міжнародних фінансових консультантів, вивчення міжнародного досвіду, очікування вдалого економічного та політичного моменту тощо. 3 цього можна дійти висновку про досить грунтовну підготовку до корпоратизації, тому в якості передумови є шанс на вдалу приватизацію.

Порядок приватизації державного майна складається з таких етапів:

- опублікування списку об’єктів, які підлягають приватизації, у виданнях органів приватизації та місцевій пресі;
- прийняття рішення щодо приватизації об'єкта;

- опублікування інформації про прийняття такого рішення;

- проведення аудиторської перевірки звітності підприємства, яке приватизується;

- проведення у випадках, визначених законодавством, екологічного аудиту певного об'єкта приватизації;

- затвердження плану приватизації [5].

Проаналізувавши процедури обох механізмів, автор провів їх порівняльно-правову характеристику. Так, фундаментальною відмінністю цих процедур є те, що внаслідок корпоратизації державне майно передається створеному товариству у власність, проте й у держави також виникають корпоративні права щодо цього товариства. Тобто, держава за собою залишає можливість управління цим товариством і отримання дивідендів від такої діяльності. Корпоратизація сприяє зміні організаційно-правової форми діяльності і більш ефективному корпоративному управлінню. Приватизація ж є способом відчуження державного майна, тобто відбувається повне вибуття майна із власності держави й перехід об'єкта до нового власника, одночасно з цим відбувається втрата будь-яких майнових і немайнових прав держави щодо приватизованого майна. У своїй публікації [6] автор звертав увагу, що в разі невиконання 30бов'язань, які були взяті стороною, може йтися про реприватизацію і повернення державі її власності, проте це лише є наслідком невиконання договору про приватизацію, а не розпорядженням майном, яке вже перейшло до іншого власника. У зв'язку із зазначеним перелік об'єктів, які можливо приватизувати, є значно меншим, ніж перелік об'єктів, які можливо корпоратизувати.

Варто звернути увагу, що об'єкти, які не підлягають приватизації, можуть піддаватися корпоратизації. Так, у справах № 7/1-08 (Про банкрутство дочірнього підприємства державної акціонерної компанії «Хліб України» "Роменський комбінат хлібопродуктів»), № 10/85/Б (про банкрутство дочірнього підприємства державної акціонерної компанії "Хліб України» «Чернівецький комбінат хлібопродуктів») [8; 9] суд касаційної інстанції погодився з висновками судів першої та апеляційної інстанцій щодо припинення провадження у справі про банкрутство з огляду на те, що до боржників не можуть бути застосовані положення Закону про банкрутство в частині санації чи ліквідації, оскільки зазначене підприємство включено до переліку об'єктів права державної власності, які не підлягають приватизації відповідно до Закону України «Про перелік об’єктів права державної власності, що не підлягають приватизації» (втратив чинність на підставі Закону № 145-IX від 02.10.2019). 
Однак судом не було враховано, що майно об’єктів, які не підлягають приватизації, було передано юридичній особі ДАК «Хліб України» в процесі корпоратизації останньої на підставі Постанови Кабінету Міністрів України «Про утворення Державної акціонерної компанії «Хліб України» [10]. При цьому корпоратизацію майна об'єктів, які не підлягали приватизації, з огляду на наведене вище слід визнати такою, яка відбулася згідно із законом. Помилковим також є поширення норм Закону України «Про управління об'єктами державної власності» на майно дочірніх підприємств ДАК «Хліб України», скільки об'єктом державної власності в цьому випадку є корпоративні права держави в ДАК, а не майно юридичної особи чи їі дочірніх підприємств [11].

Держава в майбутньому щодо корпоратизованих підприємств може відчужувати частину корпоративних прав або повністю продати свій пакет приватним суб'єктам, які за таких умов набудуть статусу власника цих корпоративних прав. Закон допускає, що корпоратизація підприємств іноді може бути першим етапом приватизації. Так, передприватизаційна підготовка державних підприємств може включати процес створення акціонерних товариств на базі державного майна або майна державного підприємства (корпоратизація). Проте в цьому випадку наступним етапом буде продаж корпоративних прав держави (всіх або їх частини) та спрямування коштів від продажу до бюджету [5].

3 корпоратизацією підприємств тісно пов'язана корпоратизація їх об'єднань і створення холдингових компаній. Крім корпоратизованих акціонерних товариств, які називають державними акціонерними товариствами, в результаті корпоратизації і приватизації з'явилися такі об'єднання: НАК - національні акціонерні компанії (НАК «Надра України», Київ; НАК «Нафтогаз України», НАК «Украгролізинг» та інші); ДАК державні акціонерні компанії (ДАК «Укрресурси», Київ); ХК - холдингові компанії (ХК «Реле і автоматика», Київ); ДАХК - державні акціонерні холдингові компанії (ДАХК «Київський радіозавод», Київ; ДАХК «Дніпровський машинобудівний завод», Дніпропетровськ; ДАХК «Чорноморський суднобудівний завод», Миколаїв)[12, с. 211].

Якщо вести мову про вплив корпоратизації на прибутковість об'єкта, то слід зазначити, що прибутковість корпоративного сектору економіки України в 2010 р. зросла майже втричі порівняно з попереднім роком. Обсяг чистого доходу господарських товариств, у статутному капіталі яких частка держави нині перевищує $50 \%$, дорівнювала 78909,6 млн грн, що майже в 2,2 рази більше, ніж у 2009 році.

Сума перерахованих дивідендів від суб'єктів підприємницької діяльності, утворених за участю держави, становить 273815,33 тис. грн.
В 2011 році спостерігалося значне зростання власного капіталу (49 603,1 млн грн), оборотних активів (51 545,8 млн грн) та первісної вартості основних засобів (93 972,2 млн грн) господарських товариств, у статутному капіталі яких державна частка перевищує $50 \%$. За рахунок джерел фінансування залучено інвестицій на суму 10950,8 млн грн. на відміну від 5396,4 млн грн y $2010 \mathrm{p}$. [13].

Важливо зазначити, що існують ризики прорахунків у процесі проведення корпоратизації стратегічно важливих підприємств в разі здійснення її відповідно до чинних процедур перетворення державних унітарних підприємств на акціонерні товариства та в порядку оцінки їх майна. Адже ці процедури є надто спрощеними, оскільки не містять чітких вимог щодо збереження виробничого профілю підприємств і розробки бізнес-планів їх розвитку.

На порядку денному нині - корпоратизація стратегічно важливих підприємств і їх перетворення на акціонерні товариства. Зокрема, існують реальні загрози поспішної корпоратизації ДП «Антонов» і пов'язаних з цим негативних наслідків. ДП «Антонов» залишається одним із не багатьох підприємств світу, яке має повний цикл виробництва і технічного обслуговування сучасних літаків. На ньому збережено науковий і кадровий потенціал, здатний створювати та виробляти продукцію, яка має попит на зарубіжних ринках. Підприємство є досить прибутковим, у реєстрі великих платників податків України в 2020 рік посідає 88-му позицію серед 1660 підприємств [14]. Тому щодо ДП «Антонов» слід дуже виважено підходити до підняття питання про корпоратизацію, i якщо воно таки буде визнано актуальним - ще виваженіше до процедури корпоратизації.

Питання доцільності і способів корпоратизації таких стратегічно важливих державних підприємств повинні прийматися 3 урахуванням світового і вітчизняного досвіду. В різних іноземних державах зазначені проблеми вирішувалися за трьома процедурами: часткова приватизація та змішана форма власності авіабудівних підприємств; їх повна приватизація із залученням стратегічного зарубіжного партнера; збереження авіабудівних підприємств у державній власності. Автор статті розглядає переваги і недоліки кожної з процедур.

Найпоширенішою $є$ часткова приватизація підприємств, коли частина акцій залишається у власності держави (Embraer, Denel, MAI). Часткову приватизацію здійснювали насамперед для полегшення тягаря, який покладається на бюджет, з метою залучення приватного інвестора та оптимізації виробництва. Причому така форма власності дала змогу зберегти частковий контроль держави і можливості для залучення капіталів. 
Прикладом успішного застосування змішаної форми власності є концерн Airbus. У 1967 р. уряд ФРН вклав 900 млн марок у проєкт Airbus. Нині концерн Arbus є конкурентом Boeing та другою в світі за потужністю авіабудівною компанією. Основна частина акцій Airbus належить державним інституціям та компаніям: $27,53 \%$ володіють уряд Франції та французький медійний концерн, $22,52 \%$ - німецький Daimler AG, 5,46\% - іспанський державний холдинг, $5,02 \%-$ російський державний «Внешэкономбанк». Решта акцій розподілена між менеджментом, інвестиційними фондами і торгується на біржах [14].

Цінним для України є досвід бразильської авіабудівної компанії Embraer. Приватизацію Embraer було здійснено шляхом аукціону 1994 року. Умови аукціону обмежували участь інших регіональних авіавиробників, частка акцій, яка могла належати іноземцям, обмежувалася $40 \%$. У власності уряду Бразилії залишилися $20 \%$ акцій і «золота акція», що давало право вето на зміну структури власності та можливість участі в прийнятті рішень щодо великих виробничих трансформацій підприємства.

За урядом було закріплене право призначати одного 311 директорів компанії. Зокрема, часткова приватизація Embraer не означала припинення державної допомоги у формі державних закупівель (воєнні замовлення, які оплачувалися авансом), фінансування НДДКР державними інституціями, кредитування покупців бразильської авіації, пільгового оподаткування, пільгових умов імпорту (на який 2005 року припадала більш як половина матеріалів і комплектуючих, що використовував Embraer) [14]. Наведений досвід показує, що запорукою успішного розвитку цієї компанії стало недопущення повної передачі права власності на акції конкурентам і збереження державою важелів впливу на управління підприємством. Крім цього, успіхи Embraer забезпечувалися й постійною та значною державною підтримкою, що дало змогу розширити обсяги та географію продажів, забезпечило компанії спроможність демпінгувати тощо.

Підвищення ефективності управління корпоративними правами держави можна досягнути за рахунок моніторингу діяльності наглядових рад, залучення до роботи в них тільки фахівців, які пройшли навчання, отримали сертифікати на право здійснення функцій з управління корпоративними правами, а також дотримання визначених критеріїв. За таких умов може й відпаде необхідність у корпоратизації й подальшій приватизації, що призведе до втрати права власності держави. За теперішніх умов держава повинна мати достатній ефективно працюючий багаж власності, щоб мати змогу забезпечити свою економічну безпеку.
В якості висновку автор зазначає, що корпоратизація і приватизація є різними процесами, які відрізняються метою, процедурою проведення та правовими наслідками. Корпоратизація державних підприємств в акціонерні товариства дала змогу створити організаційно-фінансову основу для вирішення багатьох проблем: забезпечується виведення підприємства 3-під повного підпорядкування міністерству; з'являються додаткові джерела фінансування виробничого розвитку.

Корпоративний сектор економіки фінансується насамперед за рахунок внутрішніх джерел, а також за рахунок емісій цінних паперів, кредитів тощо. Таким чином, корпоратизація сприяє наближенню умов для державних і приватних суб’єктів підприємництва, прискоренню реформування системи управління на основі зменшення адміністративних функцій міністерств і залучення приватних інвестицій. В наш час залишаються не вирішеними низка проблемних питань, які наводилися вище. До того ж процеси корпоратизації і приватизації в Україні істотно залежать як від політичної ситуації, так і від інтересів впливових фінансово-промислових груп.

Як показує світовий досвід, корпоратизація має багато переваг. Вона сприяє забезпеченню капіталізації, зростанню інвестиційної привабливості, здійсненню фінансово-економічного оздоровлення підприємств, підвищенню культури виробництва, отриманню значних коштів за рахунок розміщення акцій на фондових біржах, підвищенню конкурентоспроможності суб'єкта господарської діяльності, забезпеченню міжнародного визнання рівня управління підприємством тощо. Тому корпоратизацію з позиції захисту інтересів держави слід визнати позитивною і в багатьох випадках визначальною.

\section{Jimepamypa}

1. Про корпоратизацію підприємств : Указ Президента України від 15.06.1993 № 210/93. URL: http://zakon.rada.gov.ua/go/210/93.

2. Рябая Г.К. Становлення процесів корпоратизації в Україні. Наукові записки. 2012. Вип. 12, Част. II. C. 234-237.

3. Коментар до Проєкту Закону України «Про корпоратизацію державних підприємств» від 1 серпня 2012 року № 11057 . URL: https://ips.ligazakon.net/ document/view/lf8j500a?an=18.

4. Дзера Ю. Особливості правового режиму майна, переданого державою до статутного фонду (капіталу) акціонерного товариства в результаті корпоратизації державного унітарного підприємства. Юридична Україна. 2010. № 4. C. 59-63. URL: http://nbuv.gov.ua/ UJRN/urykr_2010_4_12.

5. Васильєва В.В. Приватизація та корпоратизація: відмінність процесів i правових наслідків. Проблеми правового забезпечення підприємництва в Україні. 2018. URL: https://doi.org/10.32849/24099201.2018.18.37. 
6. Москалюк Н.Б. Еволюція механізму реприватизації як способу набуття прав державної власності. Аль манах міжнародного права. 2017. № 18. С. 38-45.

7. Румянцев C.А. Українська модель корпоративного управління: становлення і розвиток. Київ : Т-во «Знання», КОО. 2003. $149 \mathrm{c.}$

8. Постанова Вищого господарського суду України від 27.02.2013 у справі № 7/1-08. URL: http://search.ligazakon.ua/1_doc2.nsf/link1/SD130393. html.

9. Постанова Вищого господарського суду України від 29.07.2014 у справі № 10/85/Б. URL: http://document.ua/pro-bankrutstvo-doc208632.html.

10. Про утворення Державної акціонерної компанії "Хліб України» : Постанова Кабінету Міністрів України № 1000 від 22 серпня 1996 р. URL: http://zakon.rada.gov.ua/laws/show/1000-96-п.

11. Про управління об'єктами державної власності : Закон України від 21.09.2006 № 185-V. URL: http://zakon.rada.gov.ua/laws/show/185-16.

12. Супрун Н.А. Еволюція вітчизняної моделі корпоративного управління : монографія. Київ : КНЕУ, 2009. 270 c.

13. Офіційний сайт Фонду державного майна України. Корпоративне управління. Аналітика. URL: http://www.spfu.gov.ua/ukr/fin state.php.

14. Зимовець В., Керімов П. Сценарії перерозподілу державної власності. 28.01.2020 p. URL: https://dt.ua/ economic-security/scenariyi-pererozpodilu-derzhavnoyivlasnosti-336902_.html.

\section{Анотація}

Москалюк Н. Б. Механізм корпоратизації як передумова до припинення права державної власності: історичні аспекти, сучасний стан і перспективи розвитку. - Стаття.

У статті розглянуто припинення права державної власності через механізм корпоратизації. Актуальність тематики автор вбачає у тому, що нині велика кількість об'єктів державної власності потребує підвищення ефективності управління ними. Висока конкурентна боротьба за об'єкти державної власності робить необхідним забезпечення прозорості процесів корпоратизації, суть якої полягає в перетворенні державних підприємств, закритих акціонерних товариств, більш ніж 75\% статутного фонду яких перебуває у державній власності, а також виробничих і науково-виробничих об'єднань, правовий статус яких раніше не був приведений у відповідність із чинним законодавством, у відкриті акціонерні товариства.

Корпоратизоване відкрите акціонерне товариство характеризується певною специфікою порівняно 3 іншими державними підприємствами, а тому є цікавим для наукового дослідження. Аналізуючи юридичні наслідки процесу корпоратизації, автор наполягає, що він $є$ передумовою для подальшої приватизації майна, атомувсіісторичніаспекти розвиткупроцесівкорпоратизації пов' язуються ним із приватизаційними процесами.

Значну увагу в дослідженні приділено питанню етапів корпоратизаційної процедури і їх аналізу. Автор вказує, що об'єкти, які не підлягають приватизації, можуть піддаватися корпоратизації, що сприятиме більш ефективному корпоративному управлінню.

3 корпоратизацією підприємств тісно пов'язана корпоратизація їх об'єднань і створення холдингових компаній. Автор зазначає, що нині існують ризики прорахунків у процесі проведення корпоратизації стратегічно важливих підприємств в разі здійснення ії̈ відповідно до чинних процедур перетворення державних унітарних підприємств на акціонерні товариства та в порядку оцінки їх майна. Адже ці процедури є надто спрощеними, оскільки не містять чітких вимог щодо збереження виробничого профілю підприємств і розробки бізнес-планів їх розвитку. Тому актуальним у цьому процесі є недопущення повної передачі права власності на акції конкурентам і збереження державою важелів впливу на управління стратегічним підприємством.

Ключові слова: корпоратизація, корпоративні права, роздержавлення, припинення права державної власності.

\section{Summary}

Moskaliuk N. B. Corporatization mechanism as a prerequisite for termination of state property rights: historical aspects, modern status and prospects of development. - Article.

The article deals with the termination of state ownership through the mechanism of corporatization. The author suggests the urgency of the subject in the present situation when a large number of state-owned objects need to improve their management. High competition for stateowned assets makes it necessary to ensure the transparency of corporatization processes, the essence of which is the transformation of state-owned enterprises, closed jointstock companies, more than 75 percent of the authorized capital of which is state-owned, as well as production and scientific-production associations. Their legal status has not previously been brought into conformity with applicable law into open joint-stock companies. A corporatized open joint-stock company has a certain specificity in comparison with other state-owned enterprises so it is rather interesting for scientific research.

Having analyzed the legal consequences of the corporatization process, the author insists that it is a prerequisite for the further privatization of property and therefore all historical aspects of the development of corporatization processes are linked to it by the privatization processes. Considerable attention is paid to the stages of the corporatization procedure and their analysis. The author points out that non-privatizable entities can be corporatized, which in turn will facilitate more efficient corporate governance.

Corporatization of enterprises is closely connected with corporatization of their associations and creation of holding companies. The author notes that today there are risks of miscalculations in the process of corporatization of strategically important enterprises in case of its implementation in accordance with the current procedures of transformation of state unitary enterprises into joint stock companies and in the order of valuation of their property.

These procedures are too simplistic as they do not contain clear requirements for maintaining the production profile of enterprises and developing business plans for their development. Therefore, it is urgent in this process to prevent the full transfer of share ownership to competitors and to preserve the levers of influence on the management of the strategic enterprise.

Key words: corporatization, corporate rights, divestiture, termination of state property rights. 